\title{
Antiochus I Soter may have suffered from takotsubo cardiomyopathy due to unrequited love of Strotonikea in the perspective of modern medicine
}

\author{
Hakan Gocer ${ }^{1}$, Ahmet Baris Durukan², Görkem Kokdemir ${ }^{3}$ \\ ${ }^{1}$ Department of Cardiology, Private Körfez Hospital, Edremit, Turkey \\ ${ }^{2}$ Department of Cardiovascular Surgery, Liv Ankara Hospital, Ankara, Turkey \\ ${ }^{3}$ Department of Archeology, Faculty of Language, History, and Geography, Ankara University, Ankara, Turkey
}

Kardiochirurgia i Torakochirurgia Polska 2021; 18 (2): 117-118

Takotsubo cardiomyopathy (TCM), also known as the "broken heart syndrome", is a transient cardiac syndrome involving left ventricular apical akinesis; the condition mimics acute coronary syndrome. Its name is derived from the Japanese word takotsubo, a device Japanese fishermen use to catch octopus (Figure $1 \mathrm{~A}$ ). The device has a round bottom and narrow neck, resembling the apical left ventricular ballooning [1]. TCM commonly occurs in elderly postmenopausal women aged 65 to 70 years. In contrast, the incidence in males seems to be higher in studies from Asia, ranging from $13 \%$ to $35 \%$ [2]. The disease has a reversible course and concerns systolic and diastolic left ventricular dysfunction with various wall motion abnormalities. It usually results from emotional distress, natural disasters, and the death of a loved one. The brain-heart axis has been defined in its pathophysiology with catecholamine excess [3].

Known as the ancient city of eternal love and gladiators, Stratonikeia sits on the border of the Village of Eskihisar and Yatagan, Mugla in Turkey (Figure 1 B). One of the most significant city-states in Caria, Stratonikeia, has been inhabited since the Late Bronze Age to the present day. Stephenus of Byzantium ( $6^{\text {th }}$ century AD) tells us the fascinating story of a hopeless love and disappointment.

The son of Seleukos I Nikator, the King of Caria, Antiochus I Soter (324-261 BC) [4] fell in love with his father's beautiful wife, Stratonikeia. However, this forbidden love caused much agony, and Antiochus fell ill. The King invited doctors from all around the country to find out what caused the ruthless disease. Alas, all the attempts to figure out the enigma failed. As Antiochus' condition got worse by the day, the King agonized over his boy's condition and summoned the famous doctor named Erasistratus of Ceos (304-250 BC).

Erasistratus is known as the first cardiologist mentioned in written literature since he was the first to describe the heart as the blood pump as well as the heart valves, heart rhythm, and vessels supplying the heart [5]. Erasistratus observed Antiochus for days, and he noticed that when Stratonikeia visited Antiochus' room, Antiochus' condition became worse, and his pulse increased. He experienced shortness of breath, chest pain, and his face blushed. Erasistratus diagnosed Antiochus' condition as hopeless love and told the King that there was only one remedy to cure him of his grave predicament (Figure $1 \mathrm{C}$ ). The King had to give up his wife and allow his son to marry Stratonikeia.

Eventually, Nicator left the throne, and Antiochus got married to Stratonikeia. He recovered fully, built a city dedicated to Stratonikeia and lived until sixty [6].

This ancient mythologic story reminds us of the "broken heart syndrome". We hypothesize that Antiochus's symptoms were associated with catecholamine discharge due to longing associated with the unrequited love of Stratonikeia. There are also other possible explanations of symptoms such as anxiety and related psychiatric disorders. However, we believe that the symptoms and history described above match TCM resulting from emotional distress since the symptoms experienced by the prince began when he felt disappointed and became emotionally distressed. The symptoms were consistent with heart failure, mainly tachycardia and dyspnea. He also had a decreased capacity for effort that may differentiate the diagnosis from psychiatric disorders. The critical point for diagnosis is the finding that the symptoms were aggravated when he saw Stratonikeia, the cause of emotional stress. This was stated very clearly by Bizanthion. Another clue that helps us confirm the validity of the diagnosis was the resolution of symptoms with disappearance of emotional stress when he was united with Stratonikeia.

Although TCM has occasionally been seen in males in various medical procedures (e.g. bronchoscopy, gastroscopy) and during sexual intercourse, some reports claim that hopeless love can cause TCM in younger males [2]. Based on these findings, we hypothesize that Antiochus I Soter suffered from "broken heart syndrome". To the best of our

Address for correspondence: Prof. Ahmet Baris Durukan MD, Department of Cardiovascular Surgery, Liv Ankara Hospital, Kavaklidere, Bestekar sokak No. 8, 06880 Cankaya, Ankara, Turkey, phone: +90 5322273814, e-mail: barisdurukan@yahoo.com Received: 20.11.2020, accepted: 14.03.2021. 

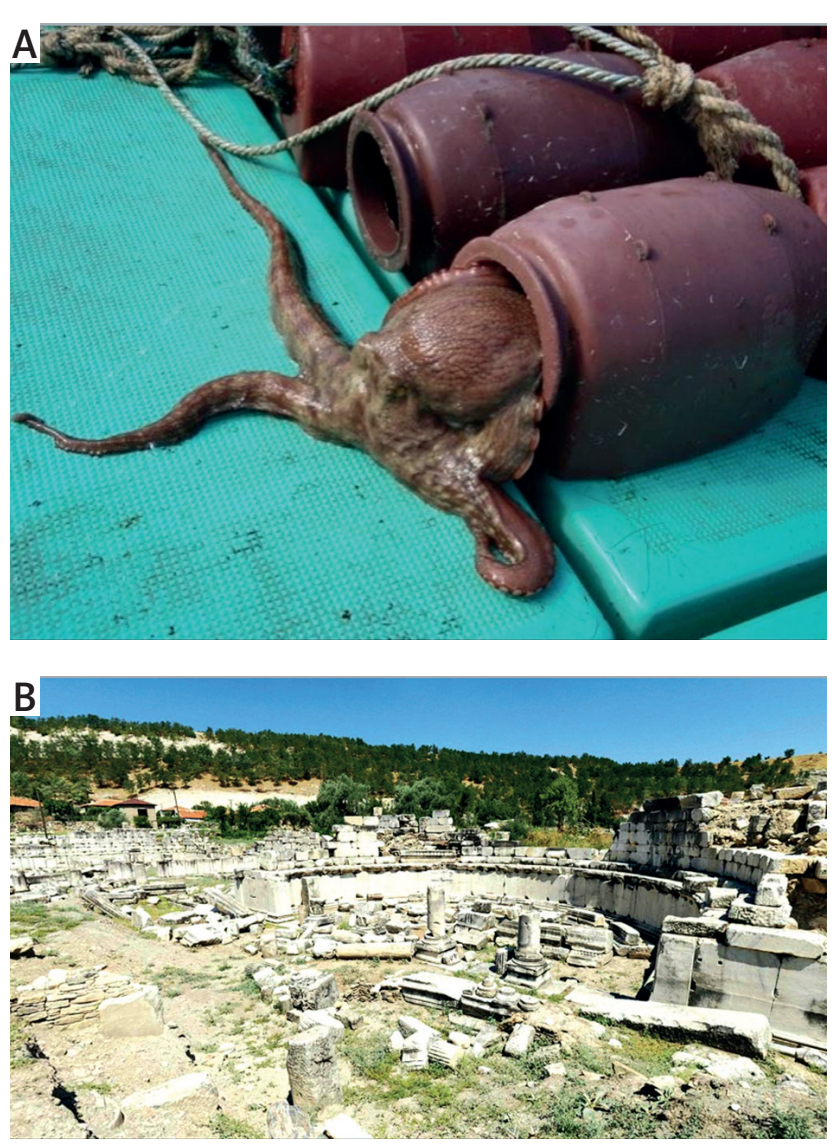

knowledge, a probable diagnosis of this historical case can be presented as TCM. Antiochus was tremendously fortunate to be diagnosed and treated by Erasistratus. We conclude that Erasistratus' diagnosis was unreservedly correct, and he was the first cardiologist described in history.

\section{Disclosure}

The authors report no conflict of interest.

\section{References}

1. Torfield A. Hikaru Sato and Takotsubo cardiomyopathy. Eur Heart J 2016; 37: 2812.

2. Amin ZH, Amin LZ, Pradipta A. Takotsubo cardiomyopathy: a brief review. J Med Life 2020; 13: 3-7.

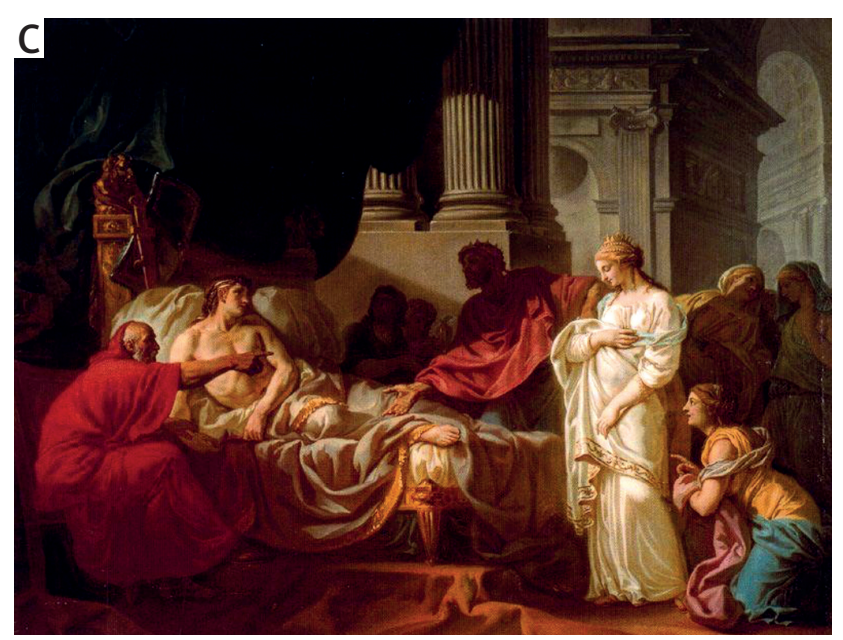

Figure 1. A - An octopus caught by the takotsubo pot. B - A recent view of Stratonikeia Ancient City. C - The painting by Jean Auguste Dominique Ingres: "Erasistratos discovering the cause of Antiochus' disease". (https://en.wikipedia.org/wiki/Erasistratus_Discovering_the_Cause_of_Antiochus\%27_Disease, accessed $15^{\text {th }}$ February 2021)

3. Templin C, Ghadri JR, Diekmann J, Napp LC, Bataiosu DR, Jaguszewski M, Cammann VL, Sarcon A, Geyer V, Neumann CA, Seifert B, Jens H, Schwyzer M, Eisenhardt K, Jenewein J, Franke J, Katus HA, Burgdorf C, Schunkert H, Moeller C, Thiele H, Bauersachs J, Tschöpe C, Schultheiss HP, Laney CA, Rajan L, Michels G, Pfister R, Ukena C, Böhm M, Erbel R, Cuneo A, Kuck KH, Jacobshagen C, Hasenfuss G, Karakas M, Koenig W, Rottbauer W, Said SM, Braun-Dullaeus RC, Cuculi F, Banning A, Fischer TA, Vasankari T, Juhani Airaksinen KE, Fijalkowski M, Rynkiewicz A, Pawlak M, Opolski G, Dworakowski R, MacCarthy P, Kaiser C, Osswald S, Galiuto L, Crea F, Dichtl W, Franz WM, Empen K, Felix SB, Delmas C, Lairez O, Erne P, Bax JJ, Ford I, Ruschitzka F, Prasad A, Lüscher TF. Clinical features and outcomes of takotsubo (stress) cardiomyopathy. N Engl J Med 2015; 373: 929-38.

4. Plutarkhos, Demetrios. 38.1-9.

5. Stok F. Medical Sects: Herophilus, Erasistratus, Empiricists. In: Oxford Handbook of Science and Medicine in the Classical World. Keyser PT, Scarborough J (eds.). Oxford 2018; 359-80.

6. Aydaş M. Stratonikeia ve Lagina. Polis ve Peripolion. In: Stratonikeia ve Çevresi Araştırmaları. Söğüt B (ed.). İstanbul 2015; 71-7. 